GUIDELINES

\title{
Guidelines on the management of ascites in cirrhosis
}

\author{
K P Moore, G P Aithal
}

\subsection{INTRODUCTION}

Ascites is a major complication of cirrhosis, ${ }^{1}$ occurring in $50 \%$ of patients over 10 years of follow up. ${ }^{2}$ The development of ascites is an important landmark in the natural history of cirrhosis as it is associated with a 50\% mortality over two years, ${ }^{2-5}$ and signifies the need to consider liver transplantation as a therapeutic option. ${ }^{3}$ The majority (75\%) of patients who present with ascites have underlying cirrhosis, with the remainder being due to malignancy $(10 \%)$, heart failure (3\%), tuberculosis $(2 \%)$, pancreatitis $(1 \%)$, and other rare causes. ${ }^{6}$ The true prevalence and incidence of cirrhosis of the liver and its complications in the UK are unknown. Mortality from cirrhosis has increased from 6 per 100000 population in 1993 to 12.7 per 100000 population in $2000 .^{7}$ Approximately $4 \%$ of the general population have abnormal liver function or liver disease ${ }^{8}$ and approximately $10-20 \%$ of those with one of the three most common chronic liver diseases (non-alcoholic fatty liver disease, alcoholic liver disease, and chronic hepatitis C) develop cirrhosis over a period of 10-20 years. With a rising frequency of alcoholic and non-alcoholic fatty liver disease, a huge increase in the burden of liver disease is expected over the next few years ${ }^{8}$ with an inevitable increase in the complications of cirrhosis. There have been several changes in the clinical management of cirrhotic ascites over recent years, and the purpose of these guidelines is to promote a consistent clinical practice throughout the UK.

These guidelines are based on a comprehensive literature search, including the results of randomised control trials, systematic reviews, prospective retrospective studies and, in some instances, evidence obtained from expert committee reports. Where possible a judgement is made on the quality of the information used to generate the guidelines, and the specific recommendations have been graded according to the Oxford Centre for Evidence-based Medicine Levels of Evidence (May 2001) (see appendices 1 and 2). ${ }^{9}$ These guidelines conform to the international guidelines recently published by the International Ascites Club $^{10}$ and are intended for use by physicians. We hope to revise these guidelines in three years time.

\subsection{DEFINITIONS}

The terms used in this article have been defined by the International Ascites Club. ${ }^{11}$

\section{Uncomplicated ascites}

Ascites that is not infected and which is not associated with the development of the hepatorenal syndrome. Ascites can be graded as follows:
6;55(Suppl VI):vil-vi12. doi: 10.1136/gut.2006.099580

- Grade 1 (mild). Ascites is only detectable by ultrasound examination.

- Grade 2 (moderate). Ascites causing moderate symmetrical distension of the abdomen.

- Grade 3 (large). Ascites causing marked abdominal distension.

\section{Refractory ascites}

Ascites that cannot be mobilised or early recurrence of which (that is, after therapeutic paracentesis) cannot be satisfactorily prevented by medical therapy. This includes two different subgroups.

- Diuretic resistant ascites-ascites that is refractory to dietary sodium restriction and intensive diuretic treatment (spironolactone $400 \mathrm{mg} /$ day and frusemide $160 \mathrm{mg} /$ day for at least one week, and a salt restricted diet of less than $90 \mathrm{mmol} /$ day ( $5.2 \mathrm{~g}$ of salt)/day).

- Diuretic intractable ascites-ascites that is refractory to therapy due to the development of diuretic induced complications that preclude the use of an effective diuretic dosage.

\subsection{PATHOGENESIS OF ASCITES FORMATION}

A detailed description of the pathogenesis of ascites formation is beyond the scope of this article but more detailed reviews are available. ${ }^{12-14}$ There are two key factors involved in the pathogenesis of ascites formation-namely, sodium and water retention, and portal (sinusoidal) hypertension.

\subsection{Role of portal hypertension}

Portal hypertension increases the hydrostatic pressure within the hepatic sinusoids and favours transudation of fluid into the peritoneal cavity. However, patients with presinusoidal portal hypertension without cirrhosis rarely develop ascites. Thus patients do not develop ascites with isolated chronic extrahepatic portal venous occlusion or non-cirrhotic causes of portal hypertension such as congenital hepatic fibrosis, except following an insult to liver function such as gastrointestinal haemorrhage. Conversely, acute hepatic vein thrombosis, causing postsinusoidal portal hypertension, is usually associated with ascites. Portal hypertension occurs as a consequence of structural changes within the liver in cirrhosis and increased splanchnic blood flow. Progressive collagen deposition and formation of nodules alter the

Abbreviations: TIPS, transjugular intrahepatic portosystemic shunt; SBP, spontaneous bacterial peritonitis; PMN, polymorphonuclear cell 
normal vascular architecture of the liver and increase resistance to portal flow. Sinusoids may become less distensible with the formation of collagen within the space of Disse. While this may give the impression of a static portal system, recent studies have suggested that activated hepatic stellate cells may dynamically regulate sinusoidal tone and thus portal pressure.

Sinusoidal endothelial cells form an extremely porous membrane which is almost completely permeable to macromolecules, including plasma proteins. In contrast, splanchnic capillaries have a pore size 50-100 times less than that of hepatic sinusoids. As a consequence, the trans-sinusoidal oncotic pressure gradient in the liver is virtually zero while it is $0.8-0.9(80 \%-90 \%$ of maximum $)$ in the splanchnic circulation. ${ }^{12}$ Oncotic pressure gradients at such extreme ends of the spectrum minimise any effect the changes in plasma albumin concentration may have on transmicrovascular fluid exchange. Therefore, the old concept that ascites is formed secondary to decreased oncotic pressure is false, and plasma albumin concentrations have little influence on the rate of ascites formation. Portal hypertension is critical to the development of ascites, and ascites rarely develops in patients with a wedged hepatic venous portal gradient of $<12 \mathrm{~mm} \mathrm{Hg} .{ }^{15}$ Conversely, insertion of a side to side portacaval shunt to decrease portal pressure often causes resolution of ascites.

\subsection{Pathophysiology of sodium and water retention}

The classical explanations of sodium and water retention occurring due to "underfill" or "overfill" are oversimplified. Patients may exhibit features of either "underfill" or "overfill" depending on posture or severity of liver disease. One of the key events thought to be critical in the pathogenesis of renal dysfunction and sodium retention in cirrhosis is the development of systemic vasodilatation, which causes a decrease in effective arterial blood volume and a hyperdynamic circulation. ${ }^{16}$ The mechanism responsible for these changes in vascular function is unknown but may involve increased vascular synthesis of nitric oxide, prostacyclin, as well as changes in plasma concentrations of glucagon, substance $\mathrm{P}$, or calcitonin gene related peptide. ${ }^{14}$

However, the haemodynamic changes vary with posture, and studies by Bernardi et al have shown marked changes in secretion of atrial natriuretic peptide with posture, as well as changes in systemic haemodynamics. ${ }^{17}{ }^{18}$ In addition, data showing a decreased effective arterial volume in cirrhosis have been disputed. ${ }^{19}$ It is agreed however that under supine conditions and in experimental animals, there is an increase in cardiac output and vasodilatation.

The development of renal vasoconstriction in cirrhosis is partly a homeostatic response involving increased renal sympathetic activity and activation of the renin-angiotensin system to maintain blood pressure during systemic vasodilatation. ${ }^{20}$ Decreased renal blood flow decreases glomerular filtration rate and thus the delivery and fractional excretion of sodium. Cirrhosis is associated with enhanced reabsorption of sodium both at the proximal tubule and at the distal tubule. ${ }^{20}$ Increased reabsorption of sodium in the distal tubule is due to increased circulating concentrations of aldosterone. However, some patients with ascites have normal plasma concentrations of aldosterone, ${ }^{21}$ leading to the suggestion that sodium reabsorption in the distal tubule may be related to enhanced renal sensitivity to aldosterone or to other undefined mechanisms. ${ }^{22}$

In compensated cirrhosis, sodium retention can occur in the absence of vasodilatation and effective hypovolaemia. Sinusoidal portal hypertension can reduce renal blood flow even in the absence of haemodynamic changes in the systemic circulation, suggesting the existence of a hepatorenal reflex. $^{23}{ }^{24}$ Similarly, in addition to systemic vasodilation, the severity of liver disease and portal pressure also contribute to the abnormalities of sodium handling in cirrhosis. ${ }^{25}$

\subsection{DIAGNOSIS}

\subsection{Initial investigations}

The underlying cause of ascites is frequently obvious from the history and physical examination. However, it is important to exclude other causes of ascites. It should not be assumed that the alcoholic patient has alcoholic liver disease. Therefore, tests must be directed at diagnosing the cause of ascites. The essential investigations on admission include a diagnostic paracentesis with measurement of ascitic fluid albumin or protein, ascitic fluid neutrophil count and culture, and ascitic fluid amylase. Ascitic fluid cytology should be requested when there is a clinical suspicion of underlying malignancy. Other investigations should include abdominal ultrasound scan to evaluate the appearance of the liver, pancreas, and lymph nodes as well as the presence of splenomegaly, which may signify portal hypertension. Blood tests should be taken for measurement of urea and electrolytes, liver function tests, prothrombin time, and full blood count.

\subsection{Abdominal paracentesis}

The commonest site for an ascitic tap is approximately $15 \mathrm{~cm}$ lateral to the umbilicus, with care being taken to avoid an enlarged liver or spleen, and is usually done in the left or the right lower abdominal quadrant. ${ }^{12}$ The inferior and superior epigastric arteries run just lateral to the umbilicus towards the mid-inguinal point and should be avoided. For diagnostic purposes, 10-20 ml of ascitic fluid should be withdrawn (ideally using a syringe with a blue or green needle) for inoculation of ascites into two blood culture bottles and an EDTA tube, and the tests outlined below. Complications of ascitic taps occur in up to $1 \%$ of patients (abdominal haematomas) but are rarely serious or life threatening. ${ }^{26}{ }^{27}$ More serious complications such as haemoperitoneum or bowel perforation are rare $(<1 / 1000$ procedures $) .^{28}$ Paracentesis is not contraindicated in patients with an abnormal coagulation profile. The majority of patients with ascites due to cirrhosis have prolongation of the prothrombin time and some degree of thrombocytopenia. There are no data to support the use of fresh frozen plasma before paracentesis although if thrombocytopenia is severe $(<40$ $000)$ most clinicians would give pooled platelets to reduce the risk of bleeding.

\section{Recommendation}

- It is recommended that patients give informed consent for a therapeutic or diagnostic paracentesis. (Level of evidence: 5; recommendation: D.)

\subsection{Ascitic fluid investigations}

\subsubsection{Ascitic fluid neutrophil count and culture}

All patients should be screened for the development of spontaneous bacterial peritonitis (SBP), which is present in approximately $15 \%$ of patients with cirrhosis and ascites admitted to hospital. ${ }^{29-31}$ An ascitic neutrophil count of $>250$ cells $/ \mathrm{mm}^{3}\left(0.25 \times 10^{9} / \mathrm{l}\right)$ is diagnostic of SBP in the absence of a known perforated viscus or inflammation of intrabdominal organs. The concentration of red blood cells in cirrhotic ascites is usually $<1000$ cells $/ \mathrm{mm}^{3}$ and bloody ascitic fluid $\left(>50,000\right.$ cells $\left./ \mathrm{mm}^{3}\right)$ occurs in about $2 \%$ of cirrhotics. ${ }^{32}$ In approximately $30 \%$ of cirrhotics with bloody ascites, there is an underlying hepatocellular carcinoma. ${ }^{33}$ 


\begin{tabular}{|ll|}
\hline $\begin{array}{l}\text { Table } 1 \text { Serum ascites-albumin gradient } \\
\text { (SA-AG) }\end{array}$ \\
\hline SA-AG $\geqslant 11 \mathrm{~g} / \mathrm{l}$ & SA-AG $<11 \mathrm{~g} / \mathrm{I}$ \\
\hline Cirrhosis & Malignancy \\
Cardiac failure & Pancreatitis \\
Nephrotic syndrome & Tuberculosis \\
\hline
\end{tabular}

However, in $50 \%$ of patients with bloody ascites, no cause can be found. ${ }^{33}$ Gram's stain of ascitic fluid is not indicated, as it is rarely helpful. ${ }^{34}$ The sensitivity of smear for mycobacteria is very poor while fluid culture for mycobacteria has a sensitivity of $50 \%{ }^{35}$ Several studies have shown that inoculation of ascitic fluid into blood culture bottles will identify an organism in approximately $72-90 \%$ of cases whereas sending ascitic fluid in a sterile container to the laboratory will only identify an organism in about $40 \%$ of cases of SBP. ${ }^{34}$ 36-39

4.3.2 Ascitic fluid protein and ascitic fluid amylase Conventionally, the type of ascites is divided into exudates and transudates, in which the ascitic protein concentration is $>25 \mathrm{~g} / \mathrm{l}$ or $<25 \mathrm{~g} / \mathrm{l}$, respectively. The purpose of this subdivision is to help identify the cause of ascites. Thus "malignancy classically causes an exudative ascites and cirrhosis causes a transudate". However, there are many misconceptions in clinical practice. For example, it is often presumed that cardiac ascites is a transudate when this is rarely the case, ascitic protein is $>25 \mathrm{~g} / \mathrm{l}$ in up to $30 \%$ of patients with otherwise uncomplicated cirrhosis, ${ }^{32}{ }^{40-43}$ and patients with cirrhosis and tuberculous ascites may have a low ascitic protein. ${ }^{44}$ The serum ascites-albumin gradient (SA-AG) is far superior in categorising ascites with 97\% accuracy (table 1). ${ }^{42} 4546$ It is calculated as:

SA-AG = serum albumin concentration - ascitic fluid albumin concentration

As a high ascitic amylase is diagnostic of pancreatic ascites, ${ }^{47-49}$ ascitic fluid amylase should be determined in patients where there is clinical suspicion of pancreatic disease.

\subsubsection{Ascitic fluid cytology}

Only $7 \%$ of ascitic fluid cytologies are positive ${ }^{50}$ yet cytological examination is $60-90 \%$ accurate in the diagnosis of malignant ascites, especially when several hundred millilitres of fluid is tested and concentration techniques are used. ${ }^{12}$ Clinicians should liaise with their local cytology department to discuss fluid requirements before paracentesis. But ascites fluid cytology is not the investigation of choice for the diagnosis of primary hepatocellular carcinoma.

\section{Recommendations}

- The initial ascitic fluid analysis should include serum ascites-albumin gradient in preference to ascitic protein. (Level of evidence: $2 b$; recommendation: B.)

- Ascitic amylase should be measured when there is clinical suspicion of pancreatic disease. (Level of evidence: 4; recommendation: C.)

- Ascitic fluid should be inoculated into blood culture bottles at the bedside and examined by microscopy for a neutrophil count. (Level of evidence: $2 a$; recommendation: B.)

\subsection{TREATMENT}

\subsection{Bed rest}

In patients with cirrhosis and ascites, assumption of upright posture is associated with activation of the renin-angiotensin-aldosterone and sympathetic nervous system, a reduction in glomerular filtration rate and sodium excretion, as well as a decreased response to diuretics. ${ }^{14}{ }^{51}$ These effects are even more striking in association with moderate physical exercise. $^{5253}$ These data strongly suggest that patients should be treated with diuretics while on bed rest. However, there have been no clinical studies to demonstrate increased efficacy of diuresis with bed rest or decreased duration of hospitalisation. As bed rest may lead to muscle atrophy, and other complications, as well as promoting extended stays in hospital, it is not generally recommended for the management of patients with uncomplicated ascites.

\section{Recommendation}

- Bed rest is NOT recommended for the treatment of ascites. (Level of evidence: 5; recommendation: D.)

\subsection{Dietary salt restriction}

Dietary salt restriction alone can create a negative sodium balance in $10 \%$ of patients. ${ }^{54}$ Sodium restriction has been associated with lower diuretic requirement, faster resolution of ascites, and shorter hospitalisation. ${ }^{55}$ In the past, dietary salt was often restricted to 22 or $50 \mathrm{mmol} /$ day. These diets may lead to protein malnutrition and a similar outcome, ${ }^{57}$ and are no longer recommended. A typical UK diet contains about $150 \mathrm{mmol}$ of sodium per day, of which $15 \%$ is from added salt and $70 \%$ is from manufactured food. ${ }^{58} 59$ Dietary salt should be restricted to $\sim 90 \mathrm{mmol} /$ day $(5.2 \mathrm{~g}$ ) salt by adopting a no-added salt diet and avoidance of pre-prepared foodstuffs (for example, pies). Dieticians' guidance and information leaflets will assist in educating patient and relatives regarding salt restriction. Certain drugs, especially those in the effervescent tablet form, have high sodium contents. Intravenous antibiotics generally contain 2.1$3.6 \mathrm{mmol}$ of sodium per gram with the exception of ciprofloxacin which contains $30 \mathrm{mmol}$ sodium in $200 \mathrm{ml}$ (400 mg) for intravenous infusion. Although in general it is preferable to avoid infusion of fluids which contain salt in patients with ascites, there are occasions, such as the development of hepatorenal syndrome or renal impairment with severe hyponatraemia, when it may be appropriate and indicated to give volume expansion with a crystalloid or colloid. For patients developing hepatorenal syndrome, the International Ascites Club recommend infusion of normal saline.

\section{Recommendation}

- Dietary salt should be restricted to a no-added salt diet

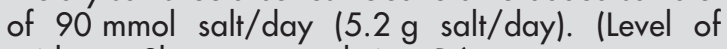
evidence: $2 b$; recommendation: $B$.)

\subsection{Role of water restriction}

There have been no studies on the benefits or harm of water restriction on the resolution of ascites. Most experts agree that there is no role for water restriction in patients with uncomplicated ascites. However, water restriction for patients with ascites and hyponatraemia has become 
standard clinical practice in many centres. However, there is real controversy about the best management of these patients, and at present we do not know the best approach. Most hepatologists treat these patients with severe water restriction. However, based on our understanding of the pathogenesis of hyponatraemia, this treatment is probably illogical and may exacerbate the severity of effective central hypovolaemia that drives the non-osmotic secretion of antidiuretic hormone (ADH). This may result in further increases in circulating $\mathrm{ADH}$, and a further decline of renal function. Impaired free water clearance is observed in 25$60 \%$ of patients with ascites due to cirrhosis, ${ }^{60}$ and many develop spontaneous hyponatraemia. ${ }^{61}$ Therefore, some hepatologists, including the authors, advocate further plasma expansion to normalise and inhibit stimulation of $\mathrm{ADH}$ release. Studies are needed to determine the best approach. ${ }^{62}$ There are data emerging that support the use of specific vasopressin 2 receptor antagonists in the treatment of dilutional hyponatraemia, ${ }^{63-65}$ but whether this improves overall morbidity and mortality is not yet known. It is important to avoid severe hyponatraemia in patients awaiting liver transplantation as it may increase the risk of central pontine myelinolysis during fluid resuscitation in surgery.

\subsection{Management of hyponatraemia in patients on diuretic therapy}

5.4 .1 Serum sodium $\geqslant 126 \mathrm{mmol} / \mathrm{l}$

For patients with ascites who have a serum sodium $\geqslant 126 \mathrm{mmol} / \mathrm{l}$, there should be no water restriction, and diuretics can be safely continued, providing that renal function is not deteriorating or has not significantly deteriorated during diuretic therapy.

\section{4 .2 Serum sodium $\leqslant 125 \mathrm{mmol} / \mathrm{l}$}

For patients with moderate hyponatraemia (serum sodium $12 \mathrm{l}-125 \mathrm{mmol} / \mathrm{l})$, opinion is divided on what is the next best course of action. The international opinion, ${ }^{10}$ in which a consensus of international experts was sought and reported, is that diuretics should be continued. However, there are no or few data to support the best course of action, and our personal view is to adopt a more cautious approach. We believe that diuretics should be stopped once serum sodium is $\leqslant 125 \mathrm{mmol} / \mathrm{l}$ and the patient observed. All experts in the field recommend stopping diuretics if serum sodium is $\leqslant 120 \mathrm{mmol} / \mathrm{l}$. If there is a significant increase in serum creatinine or serum creatinine is $>150 \mu \mathrm{mol} / \mathrm{l}$, we would recommend volume expansion. Gelofusine, haemaccel, and $4.5 \%$ albumin solutions contain sodium concentrations equivalent to normal saline $(154 \mathrm{mmol} / \mathrm{l})$. This will worsen their salt retention but we take the view that it is better to have ascites with normal renal function than to develop potentially irreversible renal failure. Water restriction should be reserved for those who are clinically euvolaemic with severe hyponatraemia in which free water clearance is decreased, and who are not currently taking diuretics, and in whom serum creatinine is normal.

\subsection{Diuretics}

Diuretics have been the mainstay of treatment of ascites since the 1940s when they first became available. Many diuretic agents have been evaluated over the years but in clinical practice in the UK this has been mainly confined to spironolactone, amiloride, frusemide, and bumetanide. These are discussed below.

\subsubsection{Spironolactone}

Spironolactone is an aldosterone antagonist, acting mainly on the distal tubules to increase natriuresis and conserve potassium. Spironolactone is the drug of choice in the initial treatment of ascites due to cirrhosis. ${ }^{66}$ The initial daily dose of

\section{Recommendations}

- Serum sodium 126-135 mmol/l, normal serum creatinine. Continue diuretic therapy but observe serum electrolytes. Do not water restrict.

- Serum sodium 121-125 mmol/l, normal serum creatinine. International opinion is to continue diuretic therapy, our opinion is to stop diuretic therapy or adopt a more cautious approach.

- Serum sodium 121-125 mmol/l, serum creatinine elevated (>150 $\mu \mathrm{mol} / \mathrm{l}$ or $>120 \mu \mathrm{mol} / \mathrm{l}$ and rising). Stop diuretics and give volume expansion.

- Serum sodium $\leqslant 120 \mathrm{mmol} / \mathrm{l}$, stop diuretics. Management of these patients is difficult and controversial. We believe that most patients should undergo volume expansion with colloid (haemaccel, gelofusine, or voluven) or saline. However, avoid increasing serum sodium by $>12 \mathrm{mmol} / \mathrm{l}$ per 24 hours.

(Level of evidence: 5; recommendation: D.)

$100 \mathrm{mg}$ may have to be progressively increased up to $400 \mathrm{mg}$ to achieve adequate natriuresis. There is a lag of 3-5 days between the beginning of spironolactone treatment and the onset of the natriuretic effect. ${ }^{67}$ Controlled studies have found that spironolactone achieves a better natriuresis and diuresis than a "loop diuretic" such as frusemide. ${ }^{68-71}$ Most frequent side effects of spironolactone in cirrhotics are those related to its antiandrogenic activity, such as decreased libido, impotence, and gynaecomastia in men and menstrual irregularity in women (although most women with ascites do not menstruate anyway). Gynaecomastia can be significantly reduced when the hydrophilic derivative potassium canrenoate is used, ${ }^{72}$ but this is not readily available in the UK. Tamoxifen at a dose $20 \mathrm{mg}$ twice a day has been shown to be useful in the management of gynaecomastia. ${ }^{73}$ Hyperkalaemia is a significant complication that frequently limits the use of spironolactone in the treatment of ascites. ${ }^{74}$

\subsubsection{Frusemide}

Frusemide is a loop diuretic which causes marked natriuresis and diuresis in normal subjects. It is generally used as an adjunct to spironolactone treatment because of its low efficacy when used alone in cirrhosis. ${ }^{71}$ The initial dose of frusemide is $40 \mathrm{mg} /$ day and it is generally increased every 23 days up to a dose not exceeding $160 \mathrm{mg} /$ day. High doses of frusemide are associated with severe electrolyte disturbance and metabolic alkalosis, and should be used cautiously. Simultaneous administration of frusemide and spironolactone increases the natriuretic effect..$^{12} 28$

\subsubsection{Other diuretics}

Amiloride acts on the distal tubule and induces diuresis in $80 \%$ of patients at doses of $15-30 \mathrm{mg} /$ day ${ }^{75}$ It is less effective compared with spironolactone or potassium canrenoate..$^{72}$ Bumetanide is similar to frusemide in its action and efficacy. ${ }^{76}$

Generally, a "stepped care" approach is used in the management of ascites starting with modest dietary salt restriction, together with an increasing dose of spironolactone. Frusemide is only added when $400 \mathrm{mg}$ of spironolactone alone has proved ineffective. ${ }^{77-79}$ In patients with severe oedema there is no need to slow down the rate of daily weight loss. ${ }^{28}$ Once the oedema has resolved but ascites persists, then the rate of weight loss should not exceed 
$\sim 0.5 \mathrm{~kg} /$ day. ${ }^{80}$ Over diuresis is associated with intravascular volume depletion (25\%) leading to renal impairment, hepatic encephalopathy (26\%), and hyponatraemia $(28 \%) .{ }^{81}$

Approximately $10 \%$ of patients with cirrhosis and ascites have refractory ascites. ${ }^{71}{ }^{82}$ In patients who fail to respond to treatment, a careful dietary and drug history should be obtained. It is important to ensure that they are not consuming drugs that are rich in sodium, or drugs that inhibit salt and water excretion such as non-steroidal anti-inflammatory drugs ${ }^{83}{ }^{84}$ Compliance with dietary sodium restriction should be monitored by measurement of urinary sodium excretion. If urinary sodium exceeds the recommended sodium intake, and the patient fails to respond to treatment, then it can be assumed that the patient is non-compliant. ${ }^{85}$

Recommendations

- Firstline treatment of ascites should be spironolactone alone, increasing from $100 \mathrm{mg} /$ day to a dose of $400 \mathrm{mg} /$ day.

- If this fails to resolve ascites, frusemide should be added in a dose of up to $160 \mathrm{mg} /$ day, but this should be done with careful biochemical and clinical monitoring.

(Level of evidence: la; recommendation: A.)

\subsection{Therapeutic paracentesis}

Patients with large or refractory ascites are usually initially managed by repeated large volume paracentesis. Several controlled clinical studies have demonstrated that large volume paracentesis with colloid replacement is rapid, safe, and effective. ${ }^{81} 86-88$ The first study demonstrated that serial large volume paracentesis (4-6 l/day) with albumin infusion ( $8 \mathrm{~g} /$ litre of ascites removed) was more effective and was associated with fewer complications and shorter duration of hospitalisation compared with diuretic therapy. ${ }^{86}$ This study was followed by other studies evaluating the efficacy, safety, speed of paracentesis, haemodynamic changes following paracentesis, and need for colloid replacement therapy. Total paracentesis is generally safer than repeated paracentesis ${ }^{89}$ if volume expansion is administered post-paracentesis. Failure to give volume expansion can lead to post-paracentesis circulatory dysfunction with impairment of renal function and electrolyte disturbances. ${ }^{90-93}$

Following paracentesis, ascites recurs in the majority $(93 \%)$ if diuretic therapy is not reinstituted, but recurs in only $18 \%$ of patients treated with spironolactone. ${ }^{94}$ Reintroduction of diuretics after paracentesis (usually within 1-2 days) does not appear to increase the risk of postparacentesis circulatory dysfunction.

\subsubsection{Haemodynamic changes following paracentesis}

Total paracentesis is associated with significant haemodynamic effects. ${ }^{91}$ It has been assumed wrongly that total paracentesis of large volumes of ascites (>10 litre) leads to circulatory collapse. Large volume paracentesis (average $>10$ litre over 2-4 hours) causes a marked reduction in intra-abdominal and inferior vena cava pressure, leading to a decrease in right atrial pressure and an increase in cardiac output. These haemodynamic changes are maximal at three hours. Pulmonary capillary wedge pressure decreases at six hours and continues to fall further in the absence of colloid replacement. On average, blood pressure decreases by $\sim 8 \mathrm{~mm} \mathrm{Hg} .{ }^{91}$ The severity of post-paracentesis circulatory dysfunction correlates inversely with patient survival..$^{95}$ There are anecdotal reports of some patients with advanced liver disease developing quite severe hypotension post-paracentesis, but this rarely occurs.

\subsubsection{Plasma expansion post paracentesis}

One study, which evaluated the haemodynamic and neurohumoral responses in 12 patients following a single $<5$ litre total paracentesis concluded that it was safe to omit the use of albumin in these patients. ${ }^{96}$ However, many experts in the field have reservations on basing such a recommendation on a single small unrandomised study. Thus the International Ascites Club recommends that a synthetic plasma expander is used if less than 5 litre is removed, and this recommendation was based on consensus rather than fact. ${ }^{10}$ Plasma volume expansion should always be used whenever $>5$ litre of ascites are removed. Serial paracentesis with and without albumin replacement have been evaluated in patients with tense ascites. ${ }^{90}$ There was a significantly higher rate of renal impairment, significant fall in serum sodium levels, and a marked activation of the renin-angiotensin-aldosterone system in those patients not treated with albumin. ${ }^{90}$

There is still some debate about whether volume expansion should be carried out using albumin or artificial plasma expanders. Analysis of individual, but relatively small and underpowered randomised controlled trials comparing dextran 70 or haemaccel/gelofusine with albumin suggest that these plasma expanders are clinically effective in the prevention of hyponatraemia and renal impairment. ${ }^{97-99}$ However, the use of artificial plasma expanders is associated with a significantly greater activation of renin-angiotensinaldosterone. ${ }^{97}$ These data suggest that if enough patients were studied, that albumin would prove to be clinically superior to haemaccel or gelofusine or dextrans. Indeed, analysis of data from all published studies also suggests that albumin is more effective in the prevention of hyponatraemia ( $8 \%$ of 482 patients) compared with $17 \%$ of 344 patients for other plasma expanders. ${ }^{100}$ A recent study by Moreau et al suggested that administration of albumin post-paracentesis decreases the number of liver related complications, and that the median hospital cost for a 30 day period was significantly lower (less than 50\%) than the cost of those treated with artificial plasma expanders. ${ }^{101}$ Until further studies are undertaken to compare the efficacy of albumin versus artificial plasma expanders, we would recommend that albumin remains the plasma expander of choice when large volume ( $>5$ litre) paracentesis is undertaken. Albumin (as $20 \%$ or $25 \%$ solution) should be infused after paracentesis of $>5$ litre is completed at a dose of $8 \mathrm{~g}$ albumin/litre of ascites removed.

\subsection{Procedure}

Paracentesis should be carried out under strict sterile conditions. The cannula should have multiple side perforations, otherwise the end becomes blocked by bowel wall. The needle is usually inserted into the left (preferably) or right lower abdominal quadrant using the " $\mathrm{Z}$ " track (skin is penetrated perpendicularly). The needle is advanced obliquely in subcutaneous tissue and then the peritoneal cavity is punctured, with the needle pointing perpendicular to the abdominal wall. This will ensure that the needle track has the puncture site on the skin and the peritoneum that do not overlie each other. All ascitic fluid should be drained to dryness in a single session as rapidly as possible over $1-4$ hours, assisted by gentle mobilisation of the cannula or turning the patient on to their side if necessary. In the author's opinion, the drain should not be left in overnight. After paracentesis, the patient should lie on the opposite side for two hours if there is leakage of any remaining ascitic fluid, and/or a suture (ideally purse string) inserted around the site of drainage. These steps help to minimise the risk of ascitic fluid leakage. 


\section{Recommendations}

- Therapeutic paracentesis is the firstline treatment for patients with large or refractory ascites. (Level of evidence: la; recommendation: A.)

- Paracentesis of $<5$ litre of uncomplicated ascites should be followed by plasma expansion with a synthetic plasma expander and does not require volume expansion with albumin (Level of evidence: $2 b$; recommendation: $B$.)

- Large volume paracentesis should be performed in a single session with volume expansion being given once paracentesis is complete, preferably using $8 \mathrm{~g}$ albu$\mathrm{min} /$ litre of ascites removed (that is, $\sim 100 \mathrm{ml}$ of $20 \%$ albumin/3 I ascites). (Level of evidence: $1 \mathrm{~b}$; recommendation: A.)

\subsection{Transjugular intrahepatic portosystemic shunt (TIPS)}

As elevated portal pressure is one of the main factors contributing to the pathogenesis of ascites, it is not surprising that TIPS is a highly effective treatment for refractory ascites. It functions as a side to side portocaval shunt that is placed under local anaesthesia and intravenous sedation, and has largely replaced the use of surgically placed portocaval or mesocaval shunts. Numerous uncontrolled studies have been published assessing the effectiveness of TIPS in patients with refractory ascites. ${ }^{102-105}$ In most studies technical success was achieved in $93-100 \%$ of cases, ${ }^{103}{ }^{106-108}$ with control of ascites achieved in $27-92 \%{ }^{103} 108109$ and complete resolution in up to $75 \%$ of cases. ${ }^{103}$ TIPS results in a secondary decrease in the activation of the renin-angiotensin-aldosterone system, and increases sodium excretion. ${ }^{110}$

Prospective randomised trials have shown TIPS to be more effective in controlling ascites compared with large volume paracentesis. ${ }^{11-113}$ However, there is no consensus regarding the impact of TIPS on transplant free survival in patients with refractory ascites. In one study TIPS had no effect on survival ${ }^{112}$ while others have reported both reduced ${ }^{111}$ as well as improved survival ${ }^{113}$ compared with therapeutic paracentesis. Moreover, TIPS also improves the overall nutritional well being of patients, but whether this is simply secondary to control of ascites and improved eating is not clear. ${ }^{110} 114115$ Hepatic encephalopathy after TIPS insertion occurs in approximately $25 \%$ of patients, and the risk is higher in those over the age of 60 years. ${ }^{116}$ TIPS is associated with less favourable outcome in advanced Child-Pugh class C patients. ${ }^{111}$ TIPS increases the cardiac preload, and hence it may precipitate heart failure in those with pre-existing heart disease. ${ }^{117}$ TIPS insertion should be considered as a treatment option for patients who require frequent paracentesis (generally $>3$ a month). TIPS has also been shown to resolve hepatic hydrothorax in $60-70 \%$ of patients. ${ }^{18-120}$

Model for end stage liver disease score, which was originally developed to predict survival following a TIPS procedure, ${ }^{121}$ has continued to evolve into a model that predicts prognosis in cirrhosis. ${ }^{122}$ According to the initial TIPS model, a risk score is calculated as

$\mathrm{R}=0.957 \times \log _{\mathrm{e}}($ creatinine $\mathrm{mg} / \mathrm{dl})+0.378 \times \log _{\mathrm{e}}($ bilirubin $\mathrm{mg} / \mathrm{dl})+1.120 \times \log _{\mathrm{e}}$ (international normalised ratio) + $0.643 \times$ (cause of cirrhosis)

where cause of cirrhosis is coded as 0 for alcoholic or cholestatic liver diseases and 1 for other causes. Please note that old units are used for both creatinine and bilirubin. Patients with a risk score $\mathrm{R}>1.8$ have a median survival of three months after elective TIPS and are considered unsuitable for the procedure unless it is being performed as a bridge to liver transplantation. ${ }^{121}$ Patients with a risk score $\mathrm{R}=1.5$ have a median survival of six months and those with $\mathrm{R}=1.3$ have a median survival of 12 months.

\section{Recommendation}

- TIPS can be used for the treatment of refractory ascites requiring frequent therapeutic paracentesis or hepatic hydrothorax with appropriate assessment of risk benefit ratio. (Level of evidence: 1b; recommendation: B.)

\subsection{PROGNOSIS}

The development of ascites is associated with a mortality of $50 \%$ within two years of diagnosis. ${ }^{2-5}$ Once ascites becomes refractory to medical therapy, $50 \%$ die within six months. ${ }^{123}$ Despite improving fluid management and patient quality of life while awaiting liver transplantation, treatments such as therapeutic paracentesis and TIPS do not improve long term survival without transplantation for most patients. ${ }^{103} 124125$ Therefore, when any patient with cirrhosis develops ascites, suitability for liver transplantation should be considered. Attention should be given to renal function in patients with ascites as pre-transplant renal dysfunction leads to greater morbidity and delayed recovery following liver transplantation and is associated with a prolonged stay in the intensive care unit and hospital. ${ }^{126-128}$

\section{Recommendation}

- Liver transplantation should be considered in patients with cirrhotic ascites. (Level of evidence: 1C; recommendation: B.)

\subsection{SPONTANEOUS BACTERIAL PERITONITIS}

Spontaneous bacterial peritonitis (SBP) is the development of a monomicrobial infection of ascites in the absence of a contiguous source of infection. SBP is a frequent and serious complication of cirrhotic patients with ascites. The prevalence of SBP in cirrhotic hospitalised patients with ascites ranges between $10 \%$ and $30 \%{ }^{29-31}$ When first described, its mortality exceeded $90 \%$ but inhospital mortality has been reduced to approximately $20 \%$ with early diagnosis and prompt treatment. ${ }^{85}$

\subsection{Diagnosis}

Patients with SBP are frequently asymptomatic. ${ }^{129} 130$ However, a significant proportion have some symptoms such as fever, mild abdominal pain, vomiting, or confusion. Diagnosis should also be suspected in those who present with hepatic encephalopathy, impairment of renal function, or peripheral leucocytosis without any obvious precipitating factor. A diagnostic paracentesis is mandatory in all patients with cirrhosis requiring hospital admission. ${ }^{31}$

\subsubsection{Ascitic fluid analysis}

The diagnosis of SBP is confirmed when ascitic neutrophil count is $>250$ cells $/ \mathrm{mm}^{3}\left(0.25 \times 10^{9} / \mathrm{l}\right)$ in the absence of an intra-abdominal and surgically treatable source of sepsis. A cutoff of 250 neutrophils $/ \mathrm{mm}^{3}$ has the greatest sensitivity although a cutoff of 500 neutrophils $/ \mathrm{mm}^{3}$ has greater 
specificity. ${ }^{131-134}$ In patients with haemorrhagic ascites with a fluid red blood cell count of $>10000 / \mathrm{mm}^{3}$ (due to concomitant malignancy or traumatic tap), subtraction of one neutrophil per $250 \mathrm{RBC}$ should be made to adjust for the presence of blood in ascites. ${ }^{31}$ Historically, neutrophil counts have been carried out by oncall microbiologists, as coulter counter determinations of neutrophil counts were inaccurate at the relatively low but pathological levels of neutrocytosis in ascitic fluid (for example, polymorphonuclear cell (PMN) count of 500 cells $/ \mathrm{mm}^{3}$ ). However, one recent study found excellent correlation between these two techniques, even at low counts, suggesting that automated counting may replace manual counts. ${ }^{135}$ Gram's stain of a smear of sediments obtained after centrifugation of ascites fluid is rarely helpful and should not be routinely requested. ${ }^{34}$

\subsubsection{Ascitic fluid culture}

This has been discussed before under ascitic fluid investigations (see above). Patients with "culture negative neutrocytic ascites" (PMN count $>250$ cells $\left./ \mathrm{mm}^{3}\left(0.25 \times 10^{9} / 1\right)\right)$ have a similar clinical presentation to those with culture positive SBP. ${ }^{136}{ }^{137}$ As both groups of patients are associated with significant morbidity and mortality, ${ }^{136}{ }^{137}$ they should be treated in a similar fashion. Some patients have "monomicrobial bacterascites" in which cultures are positive but there is normal ascitic neutrophil count. ${ }^{138}$ Such infections are thought to occur relatively commonly, and the majority are eradicated by the body's natural defence mechanisms (for example, opsonic and complement mediated bactericidal activity). ${ }^{138} 139$ When a positive culture is obtained, a further ascitic tap with a neutrophil count should be obtained. If the neutrophil is normal and patient is asymptomatic, then ignore the positive culture, but re-culture. ${ }^{138-140}$ If the neutrophil count is $>250$ cells $/ \mathrm{mm}^{3}$, then treat as per SBP.

\section{Recommendations}

- A diagnostic paracentesis should be performed in all cirrhotic patients with ascites on hospital admission. (Level of evidence 1a; recommendation A.)

- A diagnostic paracentesis should be performed in all cirrhotic patients with ascites in those who have signs and symptoms of peritoneal infection, including the development of encephalopathy, renal impairment, or peripheral leucocytosis without a precipitating factor. (Level of evidence: $2 b$; recommendation: C.)

- Ascitic fluid should be inoculated into blood culture bottles at the bedside. (Level of evidence: 2a; recommendation: B.)

\subsection{Treatment}

\subsubsection{Antibiotics}

The commonest organisms isolated in patients with SBP include Escherichia coli, gram positive cocci (mainly streptococcus species) and enterococci. These organisms account for approximately $70 \%$ of all cases of SBP. ${ }^{85}{ }^{141}$ Cefotaxime has been the most extensively investigated in patients with SBP because it covers $95 \%$ of the flora isolated from ascitic fluid and achieves high ascitic fluid concentrations during therapy. ${ }^{28}{ }^{142}$ Five days of treatment with cefotaxime is as effective as 10 day therapy, ${ }^{143}$ and low dose (2 g twice daily) is similar in efficacy to the higher doses $(2 \mathrm{~g}$ four times daily). ${ }^{144}$ Other cephalosporins, such as ceftriaxone and ceftazidime as well as co-amoxiclav (amoxicillin plus clavulanic acid), have been shown to be as effective as cefotaxime in resolving SBP. ${ }^{31}{ }^{145}$ In patients who are "well" (asymptomatic), with bowel sounds, SBP can be treated with oral antibiotics. ${ }^{27}$ Under these circumstances either oral ciprofloxacin (750 mg twice daily) or oral co-amoxiclav (1000/200 mg amoxicillin/clavulanic acid three times daily), subject to renal function, is logical.

Resolution of infection in SBP is associated with an improvement in symptoms and signs. However, for those patients who do not improve, treatment failure should be recognised early. A reduction in ascitic fluid neutrophil count of less than $25 \%$ of the pretreatment value after two days of antibiotic treatment suggests failure to respond to therapy. ${ }^{31}$ This should raise the suspicion of "secondary peritonitis" (secondary to perforation or inflammation of intra-abdominal organs) and indicate further evaluation or modification of antibiotic treatment according to in vitro sensitivity or on an empiric basis. The presence of multiple organisms in ascitic fluid is strongly suggestive of perforated bowel, and needs further urgent investigation..$^{31}$ Although algorithms, including estimation of ascetic fluid protein, glucose, lactate dehydrogenase, carcinoembryonic antigen, and alkaline phosphatase levels have been proposed to distinguish "secondary peritonitis" from SBP,,$^{146}{ }^{147}$ erect chest $x$ ray and abdominal computed tomography scan are the most useful in practice.

\subsubsection{Albumin infusion in SBP}

Development of renal impairment occurs in 30\% of patients with SBP and is one of the strongest predictors of mortality in SBP. ${ }^{146}$ A recent study suggests that cefotaxime plus albumin improves survival and decreases the incidence of renal impairment to $10 \%{ }^{149}$ This study has since been criticised as the control group were not given an equivalent amount of fluid as crystalloid. A further study has demonstrated that treatment with albumin is associated with significant improvement in circulatory function and lower frequency of endothelial dysfunction compared with equivalent doses of hydroxyethyl starch. ${ }^{150}$ But the latter study was not powered to compare clinical outcomes such as renal failure and mortality. We believe that further studies are required before making any formal recommendations about the use of albumin in SBP. However, if patients have an increased serum creatinine or a rising serum creatinine, we would support infusing $1.5 \mathrm{~g}$ albumin $/ \mathrm{kg}$ in the first six hours, followed by $1 \mathrm{~g} / \mathrm{kg}$ on day 3, which is the regimen adopted by the Barcelona group in their study on the use of albumin in SBP. ${ }^{149}$

\subsubsection{Total paracentesis for SBP}

There are no data on the role of total paracentesis in the management of SBP.

\section{Recommendations}

- In patients with an ascitic fluid neutrophil count of $>250$ cells $/ \mathrm{mm}^{3}$, empiric antibiotic therapy should be started. (Level of evidence: 1b; recommendation: A.)

- Third generation cephalosporins such as cefotaxime have been most extensively studied in the treatment of SBP and have been shown to be effective. (Level of evidence: 1a; recommendation: A.)

- Patients with SBP and signs of developing renal impairment should be given albumin at $1.5 \mathrm{~g}$ albu$\mathrm{min} / \mathrm{kg}$ in the first six hours followed by $1 \mathrm{~g} / \mathrm{kg}$ on day 3. (Level of evidence: $2 b$; recommendation: B.) 


\subsection{Prophylaxis}

For patients who have never had SBP and in whom ascitic fluid protein concentration is low $(<10 \mathrm{~g} / \mathrm{l})$, there is no consensus among experts regarding primary prophylaxis. ${ }^{31}$ In patients who survive an episode of SBP, the cumulative recurrence rate at one year is approximately $70 \%{ }^{85}$ Probability of survival at one year after an episode of SBP is $30-50 \%$ and falls to $25-30 \%$ at two years. ${ }^{151}{ }^{152}$ Therefore, patients recovering from an episode of SBP should always be considered as a potential candidate for liver transplantation. In patients who had one episode of SBP, oral norfloxacin ( $400 \mathrm{mg} /$ day) reduces the probability of recurrence of SBP from $68 \%$ to $20 \%$ and the probability of SBP due to gram negative bacilli from $60 \%$ to $3 \%{ }^{153}$ However, studies of antibiotic prophylaxis using norfloxacin or ciprofloxacin in patients with low ascites fluid protein concentration $(<15 \mathrm{~g} /$ 1) have included a heterogeneous group of patients with and without previous episodes of SBP. ${ }^{154} 155$ In the UK many centres use once daily ciprofloxacin as prophylaxis against SBP, although many also use norfloxacin. One study reported that patients with cirrhosis on long term quinolone prophylaxis developed more gram positive bacterial infections (79\%), including methicillin resistant Staphylococcus aureus, compared with predominantly gram negative infections $(67 \%)$ in those who were not on prophylaxis. ${ }^{156}$

\section{Recommendations}

- Patients recovering from one episode of SBP should receive prophylaxis with continuous oral norfloxacin $400 \mathrm{mg} /$ day (or ciprofloxacin at $500 \mathrm{mg}$ once daily). (Level of evidence: 1b; recommendation: B.)

- All patients with SBP should be considered for referral for liver transplantation. (Level of evidence: 1c; recommendation: B.)

\subsection{CONCLUSIONS}

The development of ascites is an important landmark in the natural history of cirrhosis. Adequate management of ascites is important, not only because it improves quality of life in patients with cirrhosis, but also prevents serious complication such as SBP. However, treatment of ascites does not significantly improve survival. Therefore, development of ascites should be considered as an indication for transplantation. Liver transplantation is the ultimate treatment of ascites and its complications.

Summary of recommendations: management of ascites in cirrhosis

\section{Diagnosis}

- It is recommended that patients give informed consent for a therapeutic or diagnostic paracentesis.

- The initial ascitic fluid analysis should include serum ascites-albumin gradient in preference to ascitic protein.

- Ascitic amylase should be measured when there is clinical suspicion of pancreatic disease.

- Ascitic fluid should be inoculated into blood culture bottles at the bedside and examined by microscopy for a neutrophil count.

\section{Treatment}

- Bed rest is not recommended for the treatment of ascites.

- Dietary salt should be restricted to a no added salt diet of $90 \mathrm{mmol}$ salt/day (5.2 g salt/day).

\section{Hyponatraemia}

- Serum sodium 126-135 mmol/l, normal serum creatinine. Continue diuretic therapy, but observe serum electrolytes. Do not water restrict.

- Serum sodium 121-125 mmol/l, normal serum creatinine. International opinion is to continue diuretic therapy, our opinion is to stop diuretic therapy or adopt a more cautious approach.

- Serum sodium 121-125 mmol/l, serum creatinine elevated (>150 $\mu \mathrm{mol} / /$ or $>120 \mu \mathrm{mol} / /$ and rising). Stop diuretics and give volume expansion.

- Serum sodium $\leqslant 120 \mathrm{mmol} / \mathrm{l}$, stop diuretics. The management of these patients is difficult and controversial. We believe that most patients should undergo volume expansion with colloid (haemaccel, gelofusine, or voluven) or saline. However, avoid increasing serum sodium by $>12 \mathrm{mmol} / / \mathrm{l}$ per 24 hours.

\section{Diuretics}

- Firstline treatment of ascites should be spironolactone alone, increasing from $100 \mathrm{mg} /$ day to a dose of $400 \mathrm{mg} /$ day.

- If this fails to resolve ascites, frusemide should be added in a dose of up to $160 \mathrm{mg} /$ day but this should be done with careful biochemical and clinical monitoring.

\section{Therapeutic paracentesis}

- Therapeutic paracentesis is the firstline treatment for patients with large or refractory ascites.

- Paracentesis of $<5$ litre of uncomplicated ascites should be followed by plasma expansion with a synthetic plasma expander (150-200 ml of gelofusine or haemaccel), and does not require volume expansion with albumin.

- Large volume paracentesis should be performed in a single session with volume expansion being given once paracentesis is complete, preferably using $8 \mathrm{~g}$ albu$\mathrm{min} / \mathrm{I}$ of ascites removed (that is, $\sim 100 \mathrm{ml}$ of $20 \%$ albumin/3 I ascites).

\section{TIPS procedure}

- TIPS could be used for the treatment of refractory ascites requiring frequent therapeutic paracentesis or hepatic hydrothorax with appropriate assessment of risk benefit ratio.

\section{Liver transplantation}

- Liver transplantation should be considered in patients with cirrhotic ascites.

- All patients with SBP should be considered for referral for liver transplantation. 


\section{Spontaneous bacterial peritonitis (SBP)}

\section{Diagnosis}

- A diagnostic paracentesis should be performed in all cirrhotic patients with ascites on hospital admission.

- A diagnostic paracentesis should be performed in all cirrhotic patients with ascites in those who have signs and symptoms of peritoneal infection including the development of encephalopathy, renal impairment, or peripheral leucocytosis without a precipitating factor.

- Ascitic fluid should be inoculated into blood culture bottles at the bedside.

\section{Treatment}

- In patients with ascitic fluid neutrophil count of $>250$ cells $/ \mathrm{mm}^{3}$, empiric antibiotic therapy should be started.

- Third generation cephalosporins such as cefotaxime have been most extensively studied in the treatment of SBP and have been shown to be effective.

- Patients with SBP and signs of developing renal impairment should be given albumin at $1.5 \mathrm{~g}$ albu$\mathrm{min} / \mathrm{kg}$ in the first six hours followed by $1 \mathrm{~g} / \mathrm{kg}$ on day 3.

\section{Prophylaxis}

- Patients recovering from one episode of SBP should receive prophylaxis with continuous oral norfloxacin $400 \mathrm{mg} /$ day (or ciprofloxacin at $500 \mathrm{mg}$ once daily).

\section{Authors' affiliations}

K P Moore, Royal Free and University College Medical School, University College London, London, UK

G P Aithal, Queen's Medical Centre University Hospital, Nottingham, UK

Conflict of interest: None declared.

\subsection{REFERENCES}

Kim WR, Brown JR, Terrault NA, et al. Burden of liver disease in the United States: summary of the workshop. Hepatology 2002;36:227-42.

2 Gines P, Quintero E, Arroyo V, Teres J, et al. Compensated cirrhosis: natural history and prognostic factors. Hepatology 1987;7:12-18.

3 Powell WJ, Klatskin G. Duration of survival in patients with Laennec's cirrhosis of the liver. Am J Med 1968;44:406-20.

4 D'Amico G, Morabito A, Pagliaro L, et al. Survival and prognostic indicators in compensated and decompensated cirrhosis. Dig Dis Sci 1986;31:468-75.

5 Llach J, Gines P, Arroyo V, et al. Prognostic value of arterial pressure, endogenous vasoconstrictive systems, and renal function in cirrhotic patients admitted to the hospital for the treatment of ascites. Gastroenterology 1988;94:482-7.

6 Runyon BA. Ascites. In: Schiff L, Schiff ER, eds. Diseases of the liver, 7th Edn. Philadelphia: Lippincott, 1993:990-1015.

7 Fisher NC, Hanson J, Phillips A, et al. Mortality from liver disease in the West Midlands, 1993-2000: observational study. BMJ 2002;325:312-13.

8 British Society of Gastroenterology. Care of patients with gastrointestinal disorders in the United Kingdom. An evidence based strategy for the future. London: British Society of Gastroenterology, March 2005.

9 Philips B, Ball C, Sackett D, et al. Oxford Centre for evidence-based medicine http://cebm.net/levels_of_evidence.asp\#levels (last accessed 11 August 2006).

10 Moore KP, Wong F, Gines $\mathrm{P}$, et al. The management of ascites in cirrhosis: Report on the consensus conference of the International Ascites Club. Hepatology 2003;38:258-66

11 Arroyo V, Gines P, Gerbes AL, et al. Definition and diagnostic criteria of refractory ascites and hepatorenal syndrome in cirrhosis. Hepatology 1996:23:164-76

12 Arroyo V, Gines P, Planas R, et al. Pathogenesis, diagnosis, and treatment of ascites in cirrhosis. In: Bircher J, Benhamou J-P, Mclntyre N, et al, eds. Oxford textbook of clinical hepatology. New York: Oxford University Press, Inc, 1999:697-731.
13 Dudley FJ. Pathophysiology of ascites formation. Gastroenterol Clin North Am 1992;21:215-35.

14 Gines $P$, Fernandez-Esparrach $G$, Arroyo V, et al. Pathogenesis of ascites in cirrhosis. Semin Liver Dis 1997:17:175-89.

15 Casado M, Bosch J, Garcia-Pagan JC, et al. Clinical events after transjugular intrahepatic portosystemic shunt: correlation with hemodynamic findings. Gastroenterology 1998;114:1296-303.

16 Schrier RW, Arroyo V, Bernardi M, et al. Peripheral vasodilation hypothesis: a proposal for the initiation of renal sodium and water retention in cirrhosis. Hepatology 1988;8:1151-7.

17 Bernardi M, Santini C, Trevisani F, et al. Renal function impairment induced by change in posture in patients with cirrhosis and ascites. Gut 1985;26:629-35.

18 Bernardi M, Fornale L, Di Marco C, et al. Hyperdynamic circulation of advanced cirrhosis: a re-appraisal based on posture-induced changes in hemodynamics. J Hepatol 1995;22:309-18.

19 Wong F, Liu P, Tobe S, et al. Central blood volume in cirrhosis: measurement with radionucleotide angiography. Hepatology 1994:19:312-21.

20 Arroyo V, Gines P, Rimola A, et al. Renal function abnormalities, prostaglandins and effects of non-steroidal anti-inflammatory drugs in cirrhosis with ascites. An overview with emphasis on pathogenesis. Am J Med 1986;81(suppl 2B):104-22.

21 Wilkinson SP, Jowett TP, Slater JD, et al. Renal sodium retention in cirrhosis: relation to aldosterone and nephron site. Clin Sci 1979;56:169-77.

22 Wilkinson SP, Williams R. Renin-angiotensin-aldosterone system in cirrhosis. Gut 1980;21:545-54

23 Lang F, Tschernko E, Schulze E, et al. Hepatorenal reflex regulating renal kidney function. Hepatology 1991;12:590-4.

24 Jalan R, Forrest EH, Redhead DN, et al. Reduction in renal blood flow following acute increase in the portal pressure: evidence for the existence of a hepatorenal reflex in man? Gut 1997:40:664-70.

25 Jalan R, Hayes PC. Sodium handling in patients with well compensated cirrhosis is dependent on the severity of liver disease and portal pressure. Gut 2000;46:527-33

26 Runyon BA. Paracentesis of ascites fluid: a safe procedure. Arch Int Med 1986;146:2259-61

27 McVay PA, Toy PTCY. Lack of increased bleeding after paracentesis and thoracenetesis in patients with mild coagulation abnormalities. Transfusion 1991;13:164-71.

28 Runyon BA. Management of adult patients with ascites due to cirrhosis. Hepatology 2004:39:841-56.

29 Caly WR, Strauss E. A prospective study of bacterial infections in patients with cirrhosis. J Hepatol 1993;18:353-8.

30 Bac D-J, Siersema PD, Mulder PGH, et al. Spontaneous bacterial peritonitis: outcome and predictive factors. Eur I Gastroenterol Hepatol 1993:5:635-40.

31 Rimola A, Garcia-Tsao G, Navasa M, et al. Diagnosis, treatment and prophylaxis of spontaneous bacterial peritonitis: a consensus document. $J$ Hepatol 2000;32:142-53.

32 Bar-Meir S, Lerner E, Conn HO. Analysis of ascitic fluid in cirrhosis. Dig Dis Sci 1979:24:136-44.

33 DeSitter L, Rector WG Jr. The significance of bloody ascites in patients with cirrhosis. Am J Gastroenterol 1984;79:136-8.

34 Runyon BA, Canawati HN, Akriviadis EA. Optimization of ascitic fluid culture technique, Gastroenterology 1988:95:1351-5.

35 Manohar A, Simjee AA, Pettengill KE. Symptoms and investigative findings in 145 patients with tuberculous peritonitis diagnosed by peritoneoscopy and biopsy over a five year period. Gut 1990;31:1130-2.

36 Castellote J, Xiol X, Verdaguer R, et al. Comparison of two ascitic fluid culture methods in cirrhotic patients with spontaneous bacterial peritonitis. Am J Gastroenterol 1990;85:1605-8.

37 Siersema PD, de Marie S, van Zeijl JH, et al. Blood culture bottles are superior to lysis-centrifugation tubes for bacteriological diagnosis of spontaneous bacterial peritonitis. J Clin Microbiol 1992;30:667-9.

38 Pawar GP, Gupta M, Satija VK. Evaluation of culture techniques for detection of spontaneous bacterial peritonitis in cirrhotic ascites. Indian J Gastroenterol 1994;13:139-40.

39 Runyon BA, Amillon MR, Akriviadis EA, et al. Bedside inoculation of blood culture bottles is superior to delayed inoculation in the detection of spontaneous bacterial peritonitis. J Clin Microbiol 1990;28:2811-12.

40 Sampliner RF, Iber FL. High protein ascites in patients with uncomplicated hepatic cirrhosis. Am J Med Sci 1974;267:275-9.

41 Wilson JAP, Suguitan EA, Cassidy WA, et al. Characteristics of ascitic fluid in the alcoholic cirrhotic. Dig Dis Sci 1979;24:645-8.

42 Hoefs JC. Serum protein concentration and portal pressure determine the ascitic fluid protein concentration in patients with chronic liver disease. J Lab Clin Med 1983;102:260-73.

43 Rector WG Jr, Reynolds TB. Superiority of the serum-ascites albumin difference over the ascites total protein concentration in separation of 'transudative' and 'exudative' ascites. Am J Med 1984;77:83-5.

44 Shakil AO, Korula J, Kanel GC, et al. Diagnostic features of tuberculous peritonitis in the absence and presence of chronic liver disease: a casecontrol study. Am J Med 1996:100:179-85.

45 Maver K, Manzione NC. Usefulness of the serum-ascites albumin gradient in separating transudative from exudative ascites: another look. Dig Dis Sci 1988;33:1208-12.

46 Runyon BA, Montano AA, Akriviadis EA, et al. The serum-ascites albumin gradient is superior to the exudate-transudate concept in the differential diagnosis of ascites. Ann Int Med 1992;117:215-20.

47 Runyon BA. Amylase levels in ascitic fluid. $J$ Clin Gastroenterol 1987:9:172-4. 
48 Polak M, Mattosinho Francs LC. Chronic pancreatitis with massive ascites. Digestion 1968;1:296-304

49 Schindler SC, Schaefer JW, Hull D, et al. Chronic pancreatic ascites. Gastroenterology 1970;59:453-9.

50 Runyon BA, Hoefs JC, Morgan TR. Ascitic fluid analysis in malignancyrelated ascites. Hepatology 1988;8:1104-9.

51 Ring-Larsen H, Henriksen JH, Wilken C, et al. Diuretic treatment in decompensated cirrhosis and congestive heart failure: effect of posture. BMJ 1986;292:1351-3.

52 Salo J, Gines A, Anibarro L, et al. Effect of upright posture and physical exercise on endogenous neurohumoral systems in cirrhotic patients with sodium retention and normal supine plasma renin, aldosterone, and norepinephrine levels. Hepatology 1995:22:479-87.

53 Salo J, Guevara M, Fernandez-Esparrach G, et al. Impairment of renal function during moderate physical exercise in cirrhotic patients with ascites: relationship with the activity of neurohormonal systems. Hepatology 1997;25:1338-42.

54 Gerbes AL. Medical treatment of ascites in cirrhosis. J Hepatol 1993;17:S4-9.

55 Descos L, Gauthier A, Levy VG, et al. Comparison of six treatments of ascites in patients with liver cirrhosis. Hepatogastroenterology 1983;30:15-20.

56 Gauthier A, Levy VG, Quinton A, et al. Salt or no salt in the treatment of cirrhotic ascites: a randomised study. Gut 1986;27:705-9.

57 Soulsby CT, Morgan YM. Dietary management of hepatic encephalopathy in cirrhotic patients: survey of current practice in United Kingdom. BMJ 1999;318:1391.

58 Gregory J, Foster $\mathrm{K}$, Tyler $\mathrm{H}$, et al. The dietary and nutritional survey of British adults. London: HMSO, 1990.

59 Ministry of Agriculture, Fisheries and Food. The dietary and nutritional survey of British adults - further analysis. London: Ministry of Agriculture, Fisheries and Food, 1994.

60 Bichet D, Szatalowicz V, Chaimovitz C, et al. Role of vasopressin in abnormal water excretion in cirrhotic patients. Ann Int Med 1982;96:413-17

61 Gatta A, Caregaro L, Angeli P, et al. Impaired renal water excretion in liver cirrhosis. The role of reduced distal delivery of sodium. Scand J Gastroenterol 1988;23:523-8

62 Perez-Ayuso RM, Arroyo V, Camps J, et al. Effect of demeclocycline on renal function and urinary prostaglandin E2 and kallikrein in hyponatremic cirrhotics. Nephron 1984;36:30-7.

63 Gerbes AL, Gulberg V, Gines P, et al. Therapy of hyponatremia in cirrhosis with a vasopressin receptor antagonist: a randomized double-blind multicenter trial. Gastroenterology 2003;124:933-9.

64 Fernandez-Varo G, Ros J, Cejudo-Martin P, et al. Effect of the V1a/V2-AVP receptor antagonist, Conivaptan, on renal water metabolism and systemic hemodynamics in rats with cirrhosis and ascites. J Hepatol 2003:38:755-61.

65 Wong F, Blei AT, Blendis LM, et al. A vasopressin receptor antagonist (VPA985) improves serum concentration in patients with hyponatremia: a multicenter, randomized, placebo-controlled trial. Hepatology 2003:37:182-91.

66 Santos J, Planas R, Pardo A, et al. Spironolactone alone or in combination with furosemide in the treatment of moderate ascites in nonazotemic cirrhosis. A randomized comparative study of efficacy and safety. $J$ Hepatol 2003;39: 187-92

67 Karim A. Spironolactone metabolism in man revisited. In: Brunner HR, eds. Contemporary trends in diuretic therapy. Amsterdam: Excerpta Medica, 1986:22-37.

68 Eggert RC. Spironolactone diuresis in patients with cirrhosis and ascites. BMJ 1970;4:401-3.

69 Campra JL, Reynolds TB. Effectiveness of high-dose spironolactone therapy in patients with chronic liver disease and relatively refractory ascites. Am J Dig Dis 1978;23:1025-30

70 Fogel MR, Sawhney VK, Neal EA, et al. Diuresis in the ascitic patient: a randomized controlled trial of thee regimens. J Clin Gastroenterol 1981;3(suppl 1):73-80.

71 Perez-Ayuso RM, Arroyo V, Planas R, et al. Randomized comparative study of efficacy of furosemide versus spironolactone in patients with liver cirrhosis and ascites. Gastroenterology 1983;84:961-8.

72 Angeli P, Pria MD, De Bei E, et al. Randomized clinical study of the efficacy of amiloride and potassium canreonate in nonazotemic cirrhotic patients with ascites. Hepatology 1994;19:72-9.

73 Li CP, Lee FY, Hwang SJ, et al. Treatment of mastalgia with tamoxifen in male patients with liver cirrhosis: a randomized crossover study. Am J Gastroenterol 2000;95:1051-5.

74 Sungaila I, Bartle WR, Walker SE, et al. Spironolactone pharmacokinetics and pharmacodynamics in patients with cirrhotic ascites. Gastroenterology 1992;102:1680-5

75 Yamada S, Reynolds TB. Amiloride (MK-870), a new antikaluretic diuretic. Comparison to other antikaluretic diuretics in patients with liver disease and ascites. Gastroenterology 1970;59:833-41.

76 Herlong HF, Hunter FM, Koff RS, et al. A comparison of bumetanide and furosemide in the treatment of ascites. Cooperative study. J Clin Pharmacol $1981 ; 21: 701-5$

77 Gatta A, Angeli P, Caregaro L, et al. A pathophysiological interpretation of unresponsiveness to spironolactone in a stepped-care approach to the diuretic treatment of ascites in non-azotemic cirrhotic patients. Hepatology $1991 ; 14: 231-6$.

78 Bernardi M, Laffi G, Salvagnini M, et al. Efficacy and safety of the stepped care medical treatment of ascites in liver cirrhosis: a randomized controlled clinical trial comparing two diets with different sodium content. Liver 1993; 13:156-62.
79 Takaya A, Fukui H, Matsumura M, et al. Stepped care medical treatment for cirrhotic ascites: analysis of factors influencing the response to treatment. J Gastroenterol Hepatol 1995; 10:30-5.

80 Pockros PJ, Reynolds TB. Rapid diuresis in patients with ascites from chronic liver disease: the importance of peripheral edema. Gastroenterology 1986;90:1827-33.

81 Gines P, Arroyo V, Quintero E, et al. Comparison of paracentesis and diuretics in the treatment of cirrhotics with tense ascites: results of a randomized study. Gastroenterology 1987;93:234-41.

82 Stanley MM, Ochi S, Lee KK, et al. Peritoneovenous shunting as compared with medical treatment in patients with alcoholic cirrhosis and massive ascites. N Engl J Med 1989;321:1632-8.

83 Mirouze D, Zipser RD, Reynolds TB. Effects of inhibitors of prostaglandin synthesis on induced diuresis in cirrhosis. Hepatology 1983;3:50-5.

84 Planas R, Arroyo V, Rimola A, et al. Acetylsalicylic acid suppresses the renal hemodynamic effect and reduces the diuretic action of furosemide in cirrhosis with ascites. Gastroenterology 1983;84:247-52.

85 Garcia-Tsao G. Current management of the complications of cirrhosis and portal hypertension: variceal hemorrhage, ascites, and spontaneous bacterial peritonitis. Gastroenterology 2001;120:726-48.

86 Quintero E, Gines P, Arroyo V, et al. Paracentesis versus diuretics in the treatment of cirrhotics with tense ascites. Lancet 1985;16:611-12.

87 Salerno F, Badalamenti S, Incerti $\mathrm{P}$, et al. Repeated paracentesis and i.v. albumin infusion to treat 'tense' ascites in cirrhotic patients: a safe alternative therapy, J Hepatol 1987;5:102-8

88 Acharya SK, Balwinder S, Padhee AK, et al. Large volume paracentesis and i.v. dextran to treat tense ascites. J Clin Gastroenterol 1992;14:31-5.

89 Tito L, Gines P, Arroyo V, et al. Total paracentesis associated with intravenous albumin management of patients with cirrhosis and ascites. Gastroenterology 1990;98:146-51.

90 Gines P, Tito L, Arroyo V, et al. Randomized study of therapeutic paracentesis with and without intravenous albumin in cirrhosis. Gastroenterology 1988;94:1493-502.

91 Panos MZ, Moore K, Vlavianos P, et al. Single total paracentesis for tense ascites: sequential haemodynamic changes and right atrial size. Hepatology 1990;11:667.

92 Garcia-Compean D, Villarreal JZ, Cuevas HB, et al. Total therapeutic paracentesis (TTP) with and without intravenous albumin in the treatment of cirrhotic tense ascites: a randomized controlled trial. Liver 1993;13:233-8.

93 Pozzi M. Osculati G, Boari G, et al. Time course of circulatory and humoral effects of rapid total paracentesis in cirrhotic patients with tense, refractory ascites. Gastroenterology 1994;108:709-19.

94 Fernandez-Esparrach G, Guevara M, Boari G, et al. Diuretic requirements after therapeutic paracentesis in non-azotemic patients with cirrhosis. A randomized double-blind trial of spironolactone versus placebo. J Hepato 1997;26:614-20

95 Gines A, Fernandez-Esparrach G, Monescillo A, et al. Randomized trial comparing albumin, dextran 70, and polygeline in cirrhotic patients with ascites treated by paracentesis. Gastroenterology 1996;111:1002-10.

96 Peltekian KM Wong F, Liu PP, et al. Cardiovascular, renal and neurohumoral responses to single large-volume paracentesis in cirrhotic patients with diuretic-resistant ascites. Am J Gastroenterol 1997;92:394-9.

97 Planas R, Gines P, Arroyo V, et al. Dextran-70 versus albumin as plasma expander in cirrhotic patients with ascites treated with paracentesis. Gastroenterology 1990;99:1736-44.

98 Salerno F, Badalamenti S, Lorenzano E, et al. Randomized comparative study of hemaccel vs. albumin infusion after total paracentesis in cirrhotic patients with refractory ascites. Hepatology 1991;13:707-13.

99 Fassio E, Terg R, Landeira $G$, et al. Paracentesis with dextran 70 vs. paracentesis with albumin in cirrhosis with tense ascites: Results of randomized study J Hepatol 1992;20:282-8

100 Arroyo V, Sort P, Gines P, et al. Treatment of ascites by paracentesis. In: Arroyo V, Gines P, Rodes J, Schrier RW, eds. Ascites and renal dysfunction in liver disease. Melbourne: Blackwell Science, 1999:463-79.

101 Moreau R, Valla DC, Durand-Zaleski I, et al. Comparison of outcome in patients with cirrhosis and ascites following treatment with albumin or a synthetic colloid: a randomized controlled pilot trail. Liver Int 2006;26:46-54.

102 Ferral H, Bjarnason H, Wegryn SA, et al. Refractory ascites: early experience in treatment with transjugular intrahepatic portosystemic shunt. Radiology 1993; 189:795-801

103 Ochs A, Rossle M, Haag K, et al. Transjugular intrahepatic portosystemic stent shunt procedure for refractory ascites. N Engl J Med 1995;332:1192-7.

104 Wong F, Sniderman K, Liu P, et al. The effects of transjugular portosystemic shunt on systemic and renal hemodynamics and sodium homeostasis in cirrhotic patients with refractory ascites. Ann Intern Med 1995;122:816-22.

105 Quiroga J, Sangro B, Nunez M, et al. Transjugular intrahepatic portosystemic shunt in the treatment of refractory ascites: effect on clinical, renal, humoral and hemodynamic parameters. Hepatology 1995;21:986-94

106 Crenshaw WB, Gordon FD, McEniff NJ, et al. Severe ascites-efficacy of the transjugular intrahepatic portosystemic stent shunt in treatment. Radiology 1996;200: 185-92.

107 Nazarian GK, Bjarnason H, Dietz CA Jr, et al. Effect of transjugular intrahepatic portosystemic shunt on quality of life. Radiology 1997; 205:173-80.

108 Forrest EH, Stanley AJ, Redhead DN, et al. Clinical response after intrahepatic portosystemic stent shunt insertion for refractory ascites in cirrhosis. Aliment Pharmacol Ther 1996;10:801-6.

109 Jalan R, Lui HF, Redhead DN, et al. TIPS 10 years on. Gut 2000;46:578-81. 
110 Rossle M, Siegerstetter $V$, Huber $V$, et al. The first decade of the transjugular intrahepatic portosystemic shunt (TIPS) state of the art. Liver 1998;18:73-89.

111 Lebrec D, Giuily N, Hadengue A, et al. Transjugular intrahepatic portosystemic shunts: comparison with paracentesis in patients with cirrhosis and refractory ascites: randomized trial. J Hepatol 1996;25:135-44.

112 Gines P, Uriz J, Calahorra B, et al. Transjugular intrahepatic portosystemic shunting versus paracentesis plus albumin for refractory ascites in cirrhosis. Gastroenterology 2002;123:1839-47.

113 Salerno F, Merli M, Riggio O, et al. Randomized controlled study of TIPS versus paracentesis plus albumin in cirrhosis with severe ascites. Hepatology 2004;40:629-35.

114 Rossle M, Ochs A, Gulberg V, et al. A comparison of paracentesis and transjugular intrahepatic portosystemic shunting in patients with ascites. N Engl J Med 2000;342:1701-7.

115 Allard JP, Chan J, Sandokji K, et al. Effects of ascites resolution after successful TIPS on nutrition in cirrhotic patients with refractory ascites. Am J Gastroenterol 2001;96:2442-7.

116 Sanyal AJ, Freedman AM, Shiffman ML, et al. Portosystemic encephalopathy after transjugular intrahepatic portosystemic shunt: results of a prospective controlled study. Hepatology 1994;20:46-55.

117 Huonker M, Schumacher YO, Ochs A, et al. Cardiac function and hemodynamics in alcoholic cirrhosis and effects of the transjugular intrahepatic portosystemic stent shunt. Gut 1999;44:743-8.

118 Siegerstetter V, Deibert $P$, Ochs A, et al. Treatment of refractory hepatic hydrothorax with transjugular intrahepatic portosystemic shunt: long-term results in 40 patients. Eur J Gastroenterol Hepatol 2001;13:529-34.

119 Gordon FD, Anastopoulos HT, Crenshaw W, et al. The successful treatment of symptomatic, refractory hepatic hydrothorax with transjugular intrahepatic portosystemic shunt. Hepatology 1997;25:1366-9.

120 Jeffries MA, Kazanjian S, Wilson M, et al. Transjugular intrahepatic portosystemic shunts and liver transplantation in patients with refractory hepatic hydrothorax. Liver Transpl Surg 1998;4:416-23.

121 Malinchoc M, Kamath PS, Gordon FD, et al. A model to predict poor survival in patients undergoing transjugular intrahepatic portosystemic shunts. Hepatology 2000;31:864-71

122 Kamath PS, Weisner RH, Malinchoc M, et al. A model to predict survival in patients with end-stage liver disease. Hepatology 2001;33:464-70.

123 Bories P, Garcia-Compean D, Michel H, et al. The treatment of refractory ascites by the LeVeen shunt: a multicenter controlled trial (57 patients). J Hepatol 1986;3:212-18.

124 Wong F. Transjugular intrahepatic portosystemic stent shunt for hepatorenal syndrome and ascites. Digestion 1998;59(suppl 2):41-4

125 Deschenes M, Dufresne M-P, Bui B, et al. Predictors of clinical response to transjugular intrahepatic portosystemic shunt (TIPS) in cirrhotic patients with refractory ascites. Am J Gastroenterol 1999;94:1361-5.

126 Gonwa TA, Morris CA, Goldstein RM, et al. Long-term survival and renal function following liver transplantation in patients with and without hepatorenal syndrome-experience in 300 patients. Transplantation 1991;51:428-30

127 Gonwa TA, Klintmalm GB, Levy M, et al. Impact of pretransplant renal function on survival after liver transplantation. Transplantation 1995;59:361-5

128 Brown RS, Lombardero M, Lake JR. Outcome of patients with renal insufficiency undergoing liver or liver-kidney transplantation. Transplantation 1996;62:1788-93.

129 Toledo C, Salmeron JM, Rimola A, et al. Spontaneous bacterial peritonitis in cirrhosis: predictive factors of infection resolution and survival in patients treated with cefotaxime. Hepatology 1993;17:251-7.

130 Llovet JM, Planas R, Merillas R, et al. Short-term prognosis of cirrhotics with spontaneous bacterial peritonitis: multivariate study. Am J Gastroenterol 1993;88:388-92.

131 Garcia-Tsao G, Conn HO, Lerner E. The diagnosis of bacterial peritonitis: comparison of $\mathrm{pH}$, lactate concentration and leukocyte count. Hepatology 1985;5:91-6.

132 Yang C-Y, Liaw Y-F, Chu C-M, et al. White count, $\mathrm{pH}$ and lactate in ascites in the diagnosis of spontaneous bacterial peritonitis. Hepatology 1985;5:91-6.

133 Stasscu WN, McCullough AJ, Recou BR, et al. Immediate diagnostic criteria for bacterial infection of ascitic fluid: evaluation of ascitic fluid polymorphonuclear leukocyte count, $\mathrm{pH}$ and lactate concentration, alone or in combination. Gastroenterology 1986;90:1247-54.

134 Albillos A, Cuervas-Mons V, Millan I, et al. Ascitic fluid polymorphonuclear cell count and serum in ascites albumin gradient in the diagnosis of bacterial peritonitis. Gastroenterology 1990;98:134-40.

135 Angeloni S, Nicolini G, Merli M, et al. Validation of automated blood cell counter for the determination of polymorphonuclear cell count in the ascitic fluid of cirrhotic patients with or without spontaneous bacterial peritonitis. Am J Gastroenterol 2003;98:1844-8.

136 Terg R, Levi D, Lopez $P$, et al. Analysis of clinical course and prognosis of culture-positive spontaneous bacterial peritonitis and neutrocytic ascites. Dig Dis Sci 1992;37:1499-504.

137 Pelletier G, Salmon D, Ink O, et al. Culture-negative neutrocytic ascites: less severe variant of spontaneous bacterial peritonitis. J Hepatol 1990;10:327-31

138 Runyon BA. Monomicrobial non-neutrocytic bacterascites: a variant of spontaneous bacterial peritonitis. Hepatology 1990;12:710-15.

139 Pelletier G, Lesur G, Ink O, et al. Asymptomatic bacterascites: is it spontaneous bacterial peritonitis? Hepatology 1991;14:112-15.

140 Chu C-M, Chang K-Y, Liaw Y-F. Prevalence and prognostic significance of bacterascites in cirrhosis with ascites. Dig Dis Sci 1995;40:561-5.

141 Garcia-Tsao G. Spontaneous bacterial peritonitis. Gastroenterol Clin North Am 1992;21:257-75

142 Runyon BA, Akriviadis EA, Sattler FR, et al. Ascitic fluid and serum cefotaxime and desacetylcefotaxime levels in patients treated for bacterial peritonitis. Dig Dis Sci 1991;36:1782-6.

143 Runyon BA, McHutchison JG, Antillon MR, et al. Short-course versus longcourse antibiotics treatment of spontaneous bacterial peritonitis. Gastroenterology 1991; 100:1737-42.

144 Rimola A, Salmeron JM, Clemente G, et al. Two different dosages of cefotaxime in the treatment of spontaneous bacterial peritonitis in cirrhosis: results of a prospective, randomized, multicentre study. Hepatology 1995;21:674-9.

145 Mercader J, Gomez J, Ruiz J, et al. Use of ceftrioxone in the treatment of bacterial infections in cirrhotic patients. Chemotherapy 1989;35(suppl 2):23-6.

146 Akriviadis EA, Runyon BA. Utility of an algorithm in differentiating spontaneous from secondary bacterial peritonitis. Gastroenterology 1990;98:127-33

147 Wu SS, Lim OS, Chen YY, et al. Ascitic fluid carcinoembryonic antigen and alkaline phosphatase levels for the differentiation of primary from secondary bacterial peritonitis with intestinal perforation. J Hepatol 2001;34:215-21.

148 Follo A, Llovet JM, Navasa M, et al. Renal impairment following spontaneous bacterial peritonitis in cirrhosis. Incidence, clinical course, predictive factors and prognosis. Hepatology 1994;27:1227-32

149 Sort P, Navasa M, Arroyo V, et al. Effect of intravenous albumin on renal impairment and mortality in patients with cirrhosis and spontaneous bacterial peritonitis. N Engl J Med 1999;341:403-9.

150 Fernandez J, Monteagudo J, Bargallo X, et al. A randomized unblinded pilot study comparing albumin versus hydroxyethyl starch in spontaneous bacterial peritonitis. Hepatology 2005;42:627-34.

151 Tito L, Rimola A, Gines P, et al. Recurrence of spontaneous bacteria peritonitis in cirrhosis: frequency and predictive factors. Hepatology 1988:8:27-31.

152 Altman C, Grange JD, Amiot X, et al. Survival after a first episode of spontaneous bacterial peritonitis. Prognosis of potential candidates for orthotopic liver transplantatation? J Gastroenterol Hepatol 1995;10:47-50.

153 Gines P, Rimola A, Planas R, et al. Norfloxacin prevents spontaneous bacterial peritonitis recurrence in cirrhosis: results of a double-blind, placebo-controlled trial. Hepatology 1990;12:716-24.

154 Soriano G, Guarner C, Teixido M, et al. Selective intestinal decontamination prevents spontaneous bacterial peritonitis. Gastroenterology $1991 \cdot 100 \cdot 477-81$.

155 Rolachon A, Cordier L, Bacq Y, et al. Ciprofloxacin and long-term prevention of spontaneous bacterial peritonitis: results of a prospective controlled trial. Hepatology 1995;22:1171-4.

156 Campillo B, Dupeyron C, Richardet J-P, et al. Epidemiology of severe hospital-acquired infections in patients with liver cirrhosis: effect of long-term administration of norfloxacin. Clin Infect Dis 1998;26:1066-70. 


\section{0 APPENDIX 1}

Table A2 summarises the levels of evidence according to the Oxford Centre for Evidence-based Medicine.

Table A1 Oxford Centre for Evidence-based Medicine: levels of evidence

\begin{tabular}{|c|c|c|c|c|c|}
\hline Level & $\begin{array}{l}\text { Therapy/prevention/ } \\
\text { aetiology/harm }\end{array}$ & Prognosis & Diagnosis & $\begin{array}{l}\text { Differential diagnosis/ } \\
\text { symptom prevalence study }\end{array}$ & $\begin{array}{l}\text { Economic and decision } \\
\text { analyses }\end{array}$ \\
\hline la & $\begin{array}{l}\text { SR (with homogeneity*) } \\
\text { of RCTs }\end{array}$ & $\begin{array}{l}\text { SR (with homogeneity*) of } \\
\text { inception cohort studies; } \\
\text { CDR† validated in different } \\
\text { populations }\end{array}$ & $\begin{array}{l}\text { SR (with homogeneity }{ }^{*} \text { ) of } \\
\text { level } 1 \text { diagnostic studies; } \\
\text { CDR† with } 1 \mathrm{~b} \text { studies from } \\
\text { different clinical centres }\end{array}$ & $\begin{array}{l}\text { SR (with homogeneity*) of } \\
\text { prospective cohort studies }\end{array}$ & $\begin{array}{l}\text { SR (with homogeneity*) of } \\
\text { level } 1 \text { economic studies }\end{array}$ \\
\hline $1 b$ & $\begin{array}{l}\text { Individual RCT (with } \\
\text { narrow confidence } \\
\text { interval) }\end{array}$ & $\begin{array}{l}\text { Individual inception cohort } \\
\text { study with } \geqslant 80 \% \text { follow up; } \\
\text { CDR† validated in a single } \\
\text { population }\end{array}$ & $\begin{array}{l}\text { Validating cohort study } \\
\text { with good§ reference } \\
\text { standards; or CDR† tested } \\
\text { within } 1 \text { clinical centre }\end{array}$ & $\begin{array}{l}\text { Prospective cohort study } \\
\text { with good follow up§§ }\end{array}$ & $\begin{array}{l}\text { Analysis based on clinically } \\
\text { sensible costs or alternative } \\
\text { systematic reviews of the } \\
\text { evidence and including multi- } \\
\text { way sensitivity analyses }\end{array}$ \\
\hline 1c & All or noneł & All or none case series & $\begin{array}{l}\text { Absolute SpPins and } \\
\text { SnNoutsł } ¥\end{array}$ & All or none case series & $\begin{array}{l}\text { Absolute better value or } \\
\text { worse value analysis }\end{array}$ \\
\hline $2 a$ & $\begin{array}{l}\text { SR (with homogeneity*) } \\
\text { of cohort studies }\end{array}$ & $\begin{array}{l}\text { SR (with homogeneity*) of } \\
\text { either retrospective cohort } \\
\text { studies or untreated control } \\
\text { groups in RCTs }\end{array}$ & $\begin{array}{l}\text { SR (with homogeneity*) of } \\
\text { level }>2 \text { diagnostic studies }\end{array}$ & $\begin{array}{l}\text { SR (with homogeneity*) of } \\
\text { level } 2 b \text { and better studies }\end{array}$ & $\begin{array}{l}\text { SR (with homogeneity*) of } \\
\text { level }>2 \text { economic studies }\end{array}$ \\
\hline $2 b$ & $\begin{array}{l}\text { Individual cohort study } \\
\text { (including low quality } \\
\text { RCT (<80\% follow up) }\end{array}$ & $\begin{array}{l}\text { Retrospective cohort study } \\
\text { of follow up of untreated } \\
\text { controls in an RCT; Derivation } \\
\text { of CDR† or validation on split } \\
\text { samples } \uparrow \text { only }\end{array}$ & $\begin{array}{l}\text { Exploratory cohort study } \\
\text { with good§ reference } \\
\text { standards; CDR† after } \\
\text { derivation; or validated } \\
\text { only on split samples } \\
\text { or databases }\end{array}$ & $\begin{array}{l}\text { Retrospective cohort study, } \\
\text { or poor follow-up }\end{array}$ & $\begin{array}{l}\text { Analysis based on clinically } \\
\text { sensible costs or alternatives; } \\
\text { limited reviews of the } \\
\text { evidence, or single study; } \\
\text { and including multi-way } \\
\text { sensitivity analysis }\end{array}$ \\
\hline $2 c$ & $\begin{array}{l}\text { "Outcomes" research, } \\
\text { ecological studies }\end{array}$ & "Outcomes" research & & Ecological studies & $\begin{array}{l}\text { Audit or "outcomes" } \\
\text { research }\end{array}$ \\
\hline $3 a$ & $\begin{array}{l}\text { SR (with homogeneity*) } \\
\text { of case control studies }\end{array}$ & & $\begin{array}{l}\text { SR (with homogeneity*) of } \\
3 b \text { and better studies }\end{array}$ & $\begin{array}{l}\text { SR (with homogeneity*) of } \\
3 \mathrm{~b} \text { and better studies }\end{array}$ & $\begin{array}{l}\text { SR (with homogeneity*) of } 3 \mathrm{~b} \\
\text { and better studies }\end{array}$ \\
\hline $3 b$ & $\begin{array}{l}\text { Individual case control } \\
\text { study }\end{array}$ & & $\begin{array}{l}\text { Non-consecutive study, or } \\
\text { without consistently applied } \\
\text { reference standards }\end{array}$ & $\begin{array}{l}\text { Non-consecutive study, or } \\
\text { very limited population }\end{array}$ & $\begin{array}{l}\text { Analysis based on limited } \\
\text { alternatives or costs, poor } \\
\text { quality estimates of data, but } \\
\text { including sensitivity analyses } \\
\text { incorporating clinically } \\
\text { sensible variations }\end{array}$ \\
\hline 4 & $\begin{array}{l}\text { Case series (and poor } \\
\text { quality cohort and } \\
\text { case-control studies**) }\end{array}$ & $\begin{array}{l}\text { Case series (and poor quality } \\
\text { prognostic cohort studies } \dagger+\text { ) }\end{array}$ & $\begin{array}{l}\text { Case control study, poor or } \\
\text { non-dependent reference } \\
\text { standards }\end{array}$ & $\begin{array}{l}\text { Case series or supervised } \\
\text { reference standards }\end{array}$ & $\begin{array}{l}\text { Analysis with no sensitivity } \\
\text { analysis }\end{array}$ \\
\hline 5 & $\begin{array}{l}\text { Expert opinion without } \\
\text { explicit critical appraisal } \\
\text { or based on physiology, } \\
\text { bench research or "first } \\
\text { principles" }\end{array}$ & $\begin{array}{l}\text { Expert opinion without } \\
\text { explicit critical appraisal or } \\
\text { based on physiology, bench } \\
\text { research, or "first principles" }\end{array}$ & $\begin{array}{l}\text { Expert opinion without } \\
\text { explicit critical appraisal or } \\
\text { based on physiology, bench } \\
\text { research or "first principles" }\end{array}$ & $\begin{array}{l}\text { Expert opinion without } \\
\text { explicit critical appraisal } \\
\text { or based on physiology, } \\
\text { bench research or "first } \\
\text { principles" }\end{array}$ & $\begin{array}{l}\text { Expert opinion without } \\
\text { explicit critical appraisal or } \\
\text { based on physiology, bench } \\
\text { research or "first principles" }\end{array}$ \\
\hline
\end{tabular}

SR, Systematic review; RCT, randomised controlled trial.

*Homogeneity means a systematic review that is free from worrisome variations (heterogeneity) in the results between individual studies.

†Clinical decision rules are algorithms or scoring systems leading to a diagnostic category or prognostic estimation.

¥All patients died before the therapy became available, but some survive now on it, or some died before therapy became available, but none now die on it.

-Validating studies test the quality of a diagnostic test, based on prior evidence. An exploratory study collects information and (for example, using a regression analysis) identifies which factors are significant

$\S$ Good, better, bad, and worse refer to the comparison between treatments in terms of their clinical benefit and risks.

**Poor quality cohort study is one that failed to define comparison groups and/or failed to measure exposures and outcomes in the same (preferably blinded) objective way in both exposed and non-exposed individuals, and/or failed to identify and control for confounders and/or to complete long follow up. Poor quality case control study is one that failed to define comparison groups and/or failed to measure exposures and outcomes in the same (preferably blinded) objective way in both cases and controls, and/or failed to identify and control for confounders.

††Poor quality prognostic cohort study is one with biased sampling in favour of patients who already had the target outcome, or outcomes were measured in $<80 \%$, or outcomes were determined in an unblended non-objective way, or there was no correction for the confounders.

¥¥An "absolute SpPin" is a diagnostic finding whose specificity is so high that a positive result confirms the diagnosis. "Absolute SnNout" is a diagnostic finding whose sensitivity is so high that negative results rule out the diagnosis.

" "Split sample validation is achieved by collecting all the information in a single tranche and then dividing this into "derivation" and "validation" samples.

$\S \S$ Good follow up is $>80 \%$, with adequate time for alternative diagnosis to emerge (for example, 1-8 months acute, 1-5 years chronic).

***Better value treatments are clearly as good, but cheaper or better at the same or reduced cost. Worse value treatments are as good and more expensive, or worse and equally/more expensive

\section{0 APPENDIX 2}

Table A2 summarises the grades of recommendations.

Table A2 Grades of recommendation

A Consistent level 1 studies

B Consistent level 2 or 3 studies or extrapolations from level 1 studies

C Level 4 studies or extrapolations from level 2 and 3 studies

D Level 5 evidence or troublingly inconsistent studies at any level 